Jurnal Health Sains: p-ISSN: 2723-4339 e-ISSN: 2548-1398

Vol. 3, No. 1, Januari 2022

\title{
PENINGKATAN RETENSI TENAGA KESEHATAN DI INDUSTRI JASA MELALUI STRATEGI KOMPENSASI
}

\author{
Maratu Solihah, Ratna Indrawati, Hasyim \\ Universitas Esa Unggul, Jakarta, Indonesia \\ Email: maratusolihah@yahoo.com, ratna.indrawati@esaunggul.ac.id, \\ hasyim.ahmad@esaunggul.ac.id
}

\begin{tabular}{ll}
\hline INFO ARTIKEL & ABSTRAK \\
\hline Diterima & Retensi tenaga kesehatan yang rendah dapat berdampak negatif terhadap \\
5 Januari 2022 & kinerja dan efektifitas industri jasa. Faktor penyebabnya yaitu \\
Direvisi & kompensasi tidak sesuai harapan, dan tidak adanya kompensasi berupa \\
15 Januari 2022 & lembur, insentif ataupun bonus. Penyebab lainnya yaitu masih rendahnya \\
Disetujui & komitmen organisasi tenaga kesehatan dikarenakan operasional industri \\
25 Januari 2022 & jasa yang baru berjalan satu tahun. Penelitian ini bertujuan untuk \\
Kata Kunci: & memberi bukti empiris pengaruh kompensasi dan motivasi terhadap \\
kompensasi; & retensi tenaga kesehatan dimediasi oleh komitmen organisasi. Metode \\
motivasi; komitmen & penelitian yang digunakan metode kuantitatif dengan tipe riset \\
organisasi; retensi & kausalitas. Sumber data adalah primer. Subyek analisis individu yaitu \\
tenaga kesehatan & seluruh tenaga Kesehatan dengan masa kerja lebih dari satu tahun. \\
& $\begin{array}{l}\text { Analisis data path analysis. Hasil penelitian secara simultan kompensasi, } \\
\text { motivasi dan komitmen organisasi berpengaruh positif dan signifikan }\end{array}$ \\
& terhadap retensi tenaga Kesehatan dengan komitmen organisasi sebagai \\
& intervening. Secara parsial kompensasi dan motivasi berpengaruh positif \\
& dan signifikan terhadap komitmen organisasi. Kompensasi, motivasi dan \\
& komitmen organisasi berpengaruh positif dan signifikan terhadap retensi \\
& tenaga kesehatan. Temuan penelitian pengaruh langsung kompensasi dan \\
& motivasi terhadap retensi tenaga kesehatan lebih besar dibandingkan \\
& dengan dimediasi komitmen organisasi.
\end{tabular}

\section{ABSTRACT}

Low retention of healthcare workers may contribute to a negative impact on the performance and effectiveness of the service industry, which is caused by several major factors including compensation provided by industry that does not meet employee expectations, and there is no stipulated compensation for overtime work in the form of incentives or bonuses. Furthermore, the organizational commitment of the healthcare workers is still considered low, due to the service industry's operations which have only been running for one year. This study intended to provide empirical evidence of the effect of compensation and motivation on retention of healthcare workers mediated by organizational commitment. This study utilized quantitative methods with the type of causality study. The data in this study were sourced from primary data. Individual analysis subjects consisted of all healthcare workers with a service period of more than one year. Path analysis data analysis was used in this study. The results of the study indicated that compensation, motivation and organizational commitment simultaneously had a positive and significant effect on the retention of healthcare workers with organizational commitment as an intervening variable. 


\begin{tabular}{ll}
\hline Keywords: & Furthermore, compensation and motivation partially had a positive and \\
compensation; & significant effect on organizational commitment. Moreover, \\
motivation; & ccompensation, motivation and organizational commitment contributed \\
organizational & to a positive and significant effect on the retention of healthcare \\
commitment; & workers. Findings of the study indicated that the direct effect of \\
retention of health & compensation and motivation on the retention of healthcare workers was \\
workers & greater than that mediated by organizational commitment. \\
\hline
\end{tabular}

\section{Pendahuluan}

Sumber daya manusia merupakan salah satu faktor penting dalam industri jasa, karena industri jasa sebagai Lembaga yang menghasilkan produk berupa layanan/ jasa. Elemen SDM memainkan peran penting dalam semua kegiatan yang ada dalam industri jasa (Wati et al., 2014). Oleh karena itu manajemen perlu mengembangkan program dan strategi untuk mempertahankan karyawan. Dalam upaya mengurangi terjadinya pergantian karyawan, harus dimulai dari upaya mengurangi keinginan untuk keluar (turnover intention) dan membuat karyawan ingin bertahan bekerja pada perusahaan (Susanti, et al, 2020).

Retensi karyawan merupakan suatu hal yang harus diperhatikan disetiap industri, karena pergantian karyawan mahal dan mengganggu organisasi, tim dan klien (www.eaglesflight.com). Menurut laporan yang dikumpulkan oleh Nursing Solution, Inc. tahun 2018, tingkat turnover di industri jasa saat ini adalah $16,2 \%$ dengan biaya ratarata turnover berkisar $\$ 38.900$ hingga $\$ 59.700$, biaya industri jasa rata-rata 5,13 juta hingga 7,86 juta/tahun (Wardani, 2016). Dengan demikian strategi retensi karyawan haus dipertimbangkan secara serius. Laporan yang sama menunjukkan bahwa 85,7\% industri jasa melihat retensi karyawan sebagai keharusan strategis utama, tetapi hanya 43,4\% yang memiliki strategi retensi formal. Selain itu, survei Leader for Today menunjukkan bahwa $37 \%$ profesional perawatan kesehatan berencana untuk meninggalkan industri jasa mereka saat ini dalam dua tahun ke depan, dan $68,6 \%$ berencana untuk pergi dalam lima tahun, memperkuat keseriusan masalah yang terus berlanjut

(https://www.eaglesflight.com/blog/5-

effective-employee-retention-strategies-in-

healthcare).

Kompensasi karyawan memoderasi hubungan antara jenis partisipasi karyawan dan retensi karyawan. Tujuan dari strategi retensi adalah untuk membuat karyawan setia selama mereka tinggal dengan organisasi (Potale \& Uhing, 2015). Berdasarkan pengamatan, strategi seperti aspirasi karir, otonomi, pendelegasian, keterlibatan, dan koperasi dan lingkungan kerja yang mendukung dapat menjadi faktor kunci retensi karyawan. Konsultasi manajerial, delegasi, dan dorongan sering dipandang sebagai variabel yang memiliki pengaruh pada kinerja karyawan dan retensi karyawan (Agwu, 2014). Jadi partisipasi karyawan atau keterlibatan menjadi aspek kunci dalam struktur organisasi untuk mencapai persepsi positif dari karyawan dan kepada meningkatkan efisiensi dan retensi.

Berdasarkan variabel penelitian, hasil prasurvey menunjukkan retensi tenaga kesehatan $80 \%$ dikarenakan tenaga kesehatan memiliki keluarga yang bekerja di industri jasa X Serang Banten dan 47,5\% bertahan dikarenakan belum mendapatkan pekerjaan diindustri jasa lain, berdasarkan teknik wawancara tenaga Kesehatan bertahan bekerja di industri jasa X Serang banten dikarenakan suasana kerja yang nyaman dan kekeluargaan (Banu, 2018). Pada komitmen organisasional $80 \%$ tenaga kesehatan tidak setuju dengan peraturan dan kebijakan perusahaan yang dianggap banyak yang merugikan tenaga kesehatan. Kompensasi, 95\% tenaga kesehatan menyatakan tidak ada 
kompensasi terhadap kelebihan jam kerja atau lembur dan kompensasi yang di dapatkan tidak sesuai harapan, $82,5 \%$ tenaga kesehatan menyatakan kompensasi merupakan faktor penting untuk retensi di industri jasa $\mathrm{X}$ Serang Banten. Pada motivasi, terbagi menjadi ekstrinsik dan intrinsik. Motivasi ekstrinsik yaitu motivasi yang didapat berasal dari luar individu seperti lingkungan kerja, $85 \%$ menyatakan lingkungan kerja bersifat kekeluargaan, $37,5 \%$ menyatakan industri jasa belum memberikan fasilitas sarana dan prasarana yang mendukung operasional industri jasa, $60 \%$ tenaga kesehatan merasa pimpinan unit melakukan intervensi dan tidak memberikan arahan dalam bekerja, 65\% menyatakan atasan membiarkan stafnya menyelesaikan permasalahan sendiri. Motivasi intrinsik adalah keinginan bertindak yang disebabkan oleh faktor pendorong dari dalam diri individu (Listiyani, 2011). Berdasarkan hasil presurvey $67,5 \%$ tenaga kesehatan melakukan retensi dikarenakan harapan untuk diangkat menjadi PNS.

Menurut Mathis \& Jackson, Retensi karyawan adalah suatu upaya perusahaan untuk mempertahankan karyawannya agar tetap berada di dalam organisasi yang bertujuan untuk membantu mencapai target organisasi secara lebih maksimal (Mathis \& Jackson, 2006). Retensi karyawan ditujukan agar karyawan bertahan lebih lama untuk bekerja di perusahaannya. Ini disebabkan karena perusahaan sudah melakukan investasi uang maupun waktu dalam proses recruitmen karyawan.

Menurut Meyer dan Allen berpendapat bahwa komitmen berarti penerimaan yang kuat dari individu terhadap tujuan dan nilainilai organisasi, dan individu berupaya serta berkarya dan memiliki keinginan yang kuat untuk tetap bertahan pada organisasi tersebut (Meyer \& Allen, 1997). Indikator yang digunakan adalah komitmen afektif, komitmen normative dan komitmen berkelanjutan.
William B. Wether dan Keith Davis mengatakan kompensasi adalah apa yang diterima karyawan sebagai imbalan dari pekerjaan mereka. Baik upah per jam atau gaji berkala, bagian personalia biasanya merancang dan mengelola kompensasi karyawan (Werther \& Davis, 1989). Kompensasi terbagi menjadi kompensasi langsung seperti gaji, insentif dan bonus dan kompensasi tidak langsung berupa semua imbalan finansial yang tidak tercakup dalam kompensasi langsung seperti penghargaan.

Menurut Mc Clelland motivasi kerja dapat diartikan sebagai dorongan dan semangat yang menjadi dasar seseorang dalam melaksanakan tugasnya, yang dapat dinilai dari pengembangan diri, pengakuan hasil kerja, penghargaan, pengakuan keberadaan, bekerjasama, kepatuhan dan hubungan dengan atasan (McClelland, 1987).

Penelitian sebelumnya yang dilakukan oleh Kigathi Patric Ngure, memberikan kesimpulan bahwa bahwa gaya kepemimpinan mempengaruhi retensi petugas kesehatan di Industri jasa Nasional Kenya. Remunerasi bagi petugas kesehatan memang mempengaruhi retensi mereka. Pelatihan yang ditawarkan juga mempengaruhi retensi tenaga kesehatan. Promosi mempengaruhi retensi petugas kesehatan di Industri jasa Nasional Kenyatta (Basri, 2014). Remunerasi yang adil juga direkomendasikan untuk meningkatkan motivasi dan stabilitas pekerja kesehatan. Pelatihan staf petugas kesehatan direkomendasikan sebagai cara untuk meningkatkan keterampilan dan pengetahuan petugas kesehatan yang berfungsi sebagai motivasi intrinsik bagi petugas kesehatan juga. Kebijakan promosi dan pelatihan harus ditaati di agar tercipta rasa keadilan organisasi di kalangan tenaga kesehatan (Ngure \& Waiganjo, 2017).

\section{Metode Penelitian}

Penelitian ini menggunakan pendekatan kuantitatif, dilakukan pada bulan 
Oktober sampai dengan November 2020. Populasi pada penelitian ini adalah keseluruhan tenaga Kesehatan dengan masa kerja lebih dari satu tahun RS X Serang Banten berjumlah 67 responden

Jumlah sampel dalam penelitian ini menggunakan teknik non probability sampling metode purposive dengan kriteria eksklusi Dalam penelitian yang dikeluarkan dari kelompok responden adalah tenaga Kesehatan dengan masa kerja kurang dari satu tahun. Instrumen penelitian yang

\section{Hasil dan Pembahasan}

\section{A. Hasil Analisis Deskriptif}

67 responden yang diteliti, jumlah responden perempuan lebih banyak dari responden laki-laki dengan persentase responden perempuan yaitu 48 orang $(72 \%)$ dan laki-laki 19 orang (28\%). Sebagian besar usia responden 20-30 tahun sebanyak 46 orang (69\%). Sebagian digunakan dalam penelitian ini menggunakan angket kuisioner dengan skala likert

Uji validitas menggunakan Pearson Product Moment Correlation, suatu variabel dikatakan valid jika nilai $r$ hitung $>r$ tabel., hasil uji reliabilitas dengan menggunakan uji Cronbach Alpha $(\alpha)>0,6$, diperoleh hasil bahwa variable kompensasi, motivasi, komitmen organisasi dan retensi tenaga kesehatan semua reliabel. Analisis data dalam penelitian ini menggunakan software statistik.

besar responden memiliki pendidikan D3 sebanyak 35 orang $(52 \%)$. Untuk unit kerja perawat sebanyak $43 \%$, bidan $30 \%$ dan dokter $27 \%$.

Hasil deskripsi jawaban responden tentang sikap dalam berperilaku ditunjukkan dalam matrix perilaku dalam tabel 1 sebagai berikut:

Tabel 1

Matrix Tanggapan Responden

\begin{tabular}{|c|c|c|c|c|c|}
\hline \multirow{2}{*}{ No } & \multirow{2}{*}{ Variabel } & \multicolumn{4}{|c|}{ Posisi Tanggapan Responden } \\
\hline & & Rendah & Sedang & Tinggi & Perilaku \\
\hline 1 & Kompensasi & $*$ & & & $\begin{array}{l}\text { Tidak } \\
\text { Loyal }\end{array}$ \\
\hline 2 & Motivasi & & & $*$ & Semangat \\
\hline 3 & $\begin{array}{l}\text { Komitmen } \\
\text { Organisasi }\end{array}$ & & $*$ & & Berdedikas \\
\hline 4 & Retensi & & $*$ & & Bertahan \\
\hline
\end{tabular}

Dari tabel 1 diatas maka didapat tanggapan responden kompensasi yang diberikan oleh industri jasa X Serang Banten dianggap tenaga Kesehatan tidak loyal tetapi pada motivasi memiliki semangat kerja tinggi Tenaga Kesehatan B. Pengujian Hipotesis

Dari 67 responden seluruh sample dapat diolah dengan menggunakan software statistik. 


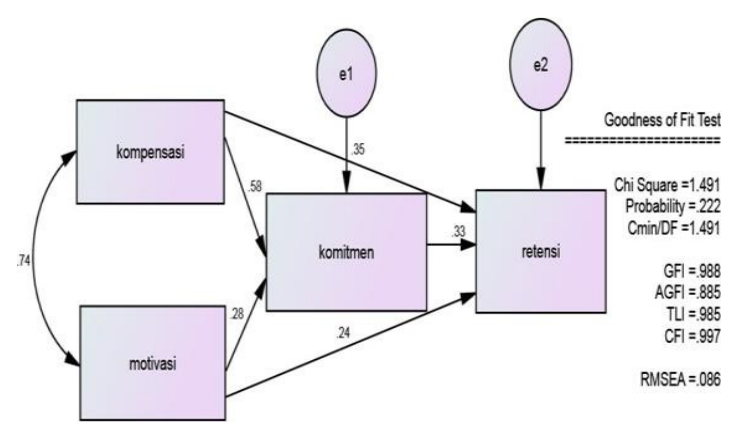

\section{Pengujian Hipotesis}

Dari 67 responden seluruh sample dapat diolah dengan menggunakan software statistic.

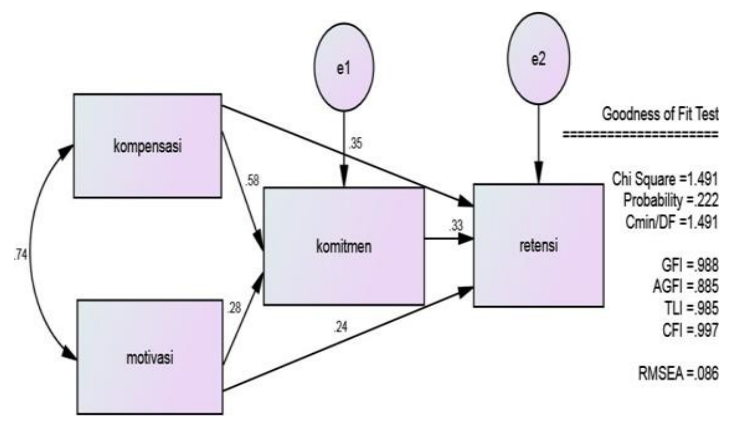

\section{Uji Normalitas}

Uji normalitas menguji apakah dalam sebuah model analisis jalur, variabel dependen, variabel independen atau keduanya mempunyai distribusi normal atau tidak normal. Untuk mendeteksi normalitas secara Bersamasama (multivariate), dapat dilihat dari nilai cr dari kurtosis pada baris terakhir lebih besar dari \pm 2.58. Pada table 2 dapat dilihat nilai cr pada kurtosis baris terakhir adalah 1,392.

Tabel 2

Data Uji Normalitas

\begin{tabular}{|l|c|c|l|l|l|l|}
\hline \multicolumn{1}{|c|}{ Variabel } & Min & Max & \multicolumn{1}{c|}{ Skew } & \multicolumn{1}{c|}{ Cr } & Kurtosis & \multicolumn{1}{c|}{ Cr } \\
\hline Kompensasi & 1.200 & 3.600 & .448 & 1.496 &,- 051 &,- 086 \\
\hline Motivasi & 2.083 & 4.833 & -.677 & -2.262 &,- 249 & -.416 \\
\hline Komitmen & 2,625 & 4,375 &,- 409 & -1.366 & -1.362 & -2.275 \\
\hline Retensi & 2.273 & 4,545 &, 236 & .790 & -.953 & -1.592 \\
\hline Multivariate & & & & & 2,357 & $\mathbf{1 , 3 9 2}$ \\
\hline
\end{tabular}

Sumber hasil analisis data AMOS-path analysis

\section{E. Uji Multikolinearitas}

Uji ini dilakukan dengan melihat determinan matrikx kovarians. Jika nilainya sangat kecil mengindikasikan terjadinya multikolinearitas. Dalam penelitian ini didapatkan nilai determinan matriks kovarian hasilnya 0.001 (hasil positif dan lebih besar dari 0.000 ) artinya tidak ada multikolinearitas.

\section{F. Uji Parsial}

Berdasarkan tabel di bawah ini menunjukkan bahwa pengaruh kompensasi dan motivasi terhadap komitmen organisasi. Pengaruh komitmen organisasi terhadap retensi tenaga kesehatan serta pengaruh kompensasi dan motivasi terhadap retensi tenaga Kesehatan. 
Peningkatan Retensi Tenaga Kesehatan di Industri Jasa Melalui Strategi Kompensasi

Tabel 3

Uji Hipotesa

Regression Weight (Group number 1 - Default model)

\begin{tabular}{lllllll}
\hline Variabel & Variabel & Estimate & S.E. & C.R. & P & Ket \\
\hline \multirow{2}{*}{ Kompensasi } & $\rightarrow \begin{array}{l}\text { Komitmen } \\
\text { Organisasi }\end{array}$ & 0,559 & $\mathbf{1 0 2}$ & $\mathbf{5 , 4 8 5}$ & $*$ & $\begin{array}{l}(\mathrm{H} 2) \\
\text { Diterima }\end{array}$ \\
\hline Motivasi & $\rightarrow$ Komitmen & 0,281 &, 107 & 2,635 & $\begin{array}{l}0,0 \\
08\end{array}$ & $\begin{array}{l}(\mathrm{H} 3) \\
\text { Diterima }\end{array}$ \\
\hline $\begin{array}{l}\text { Komitmen } \\
\text { Organisasi }\end{array}$ & $\rightarrow$ Retensi & 0,342 &, 117 & 2,921 & $\begin{array}{l}0,0 \\
03\end{array}$ & $\begin{array}{l}(\mathrm{H} 4) \\
\text { Diterima }\end{array}$ \\
\hline Kompensasi & $\rightarrow$ Retensi & 0,344 &, 117 & 2,942 & $\begin{array}{l}0,0 \\
03\end{array}$ & $\begin{array}{l}\text { (H5) } \\
\text { Diterima }\end{array}$ \\
\hline Motivasi & $\rightarrow$ Retensi & 0,243 &, 107 & 2,286 & $\begin{array}{l}0,0 \\
22\end{array}$ & $\begin{array}{l}\text { (H6) } \\
\text { Diterima }\end{array}$ \\
\hline
\end{tabular}

Pengaruh kompensasi dan motivasi terhadap retensi tenaga Kesehatan dengan komitmen organisasi sebagai variabel intervening

Uji model measurement adalah menguji hubungan antara indikator dengan variabel laten. Digabungkan pengujian model struktural dan pengukuran tersebut memungkinkan peneliti untuk menguji measurement error sebagai bagian yang tidak terpisahkan dari software statistik serta melakukan analisis faktor bersamaan dengan pengujian hipotesis. Menunjukkan bahwa terdapat pengaruh antara kompensasi, motivasi dan komitmen organisasi terhadap retensi tenaga kesehatan.

Nilai estimate yang didapatkan dari variabel kompensasi, motivasi dan komitmen organisasi terhadap retensi tenaga Kesehatan adalah sebesar 0.712 . Artinya variabel kompensasi, motivasi dan komitmen organisasi mempengaruhi retensi tenaga Kesehatan sebesar 71,2\%, sedangkan sisanya $28,8 \%$ dipengaruhi oleh variabel lain diluar penelitian ini seperti lingkungan kerja dan loyalitas karyawan.

Berdasarkan Analisa distribusi responden dengan menggunakan three box methode, Nilai indeks tertinggi terdapat pada RET14 indikator hubungan karyawan yaitu "Saya merasa hubungan para tenaga kesehatan di perusahaan sangat baik dan akrab" dengan nilai indeks 54,4. Nilai indeks terendah terdapat pada RET7 indikator penghargaan dengan nilai 29,6 yaitu "Penghargaan yang diterima berwujud pujian dan bonus serta tunjangan yang kompetitif dari industri jasa", terdapat $73,13 \%$ karyawan tidak setuju dengan system penghargaan yang ada di industri jasa. Sistem rancangan tugas dan pekerjaan serta hubungan antar tenaga kesehatan di industri jasa sudah berjalan baik, tetapi system peluang karir yang dibuat oleh manajemen industri jasa belum sesuai dengan harapan tenaga kesehatan.

Pada indikator penghargaan terdapat nilai indeks rendah lainnya 31 yaitu pada pernyataan RET10 "Perusahaan memberikan insentif yang sesuai dengan prestasi kerja tenaga kesehatan" terdapat $71,6 \%$ karyawan yang tidak setuju dengan pernyataan tersebut. Pada indikator peluang karir nilai indeks terendah 32,6 masuk kategori sedang pernyataan RET5 "Saya memiliki kesempatan dan peluang untuk mendapatkan promosi" terdapat 55,2 \% karyawan yang tidak setuju dengan pernyataan tersebut. Pada RET6 dengan nilai indeks 33 "Manajer saya memberikan program bimbingan secara rutin untuk meningkatkan kemampuan dan pengalaman bawahannya" terdapat 59,7 \% 
karyawan tidak setuju dengan pernyataan tersebut. Artinya retensi tenaga Kesehatan masih rendah karena tenaga kesehatan dapat dengan mudah pindah ke industri jasa lain yang menawarkan pekerjaan lebih baik.

Retensi karyawan (employee retention) adalah bentuk atau cara mempertahankan karyawan agar tetap bekerja dalam perusahaan tersebut. Dalam sebuah perusahaan tidak terlepas dari karyawan atau pegawai. Terdapat perilaku yang sangat beragam dari karyawan merupakan hal yang sangat biasa dijumpai diperusahaan. Barang atau asset yang tak ternilai dalam sebuah perusahaan adalah karyawan yang dimilikinya. Retensi karyawan adalah suatu upaya perusahaan untuk mempertahankan karyawannya agar tetap berada di dalam organisasi yang bertujuan untuk membantu mencapai target organisasi secara lebih maksimal (Mathis \& Jackson, 2006)

Pengaruh kompensasi terhadap komitmen organisasi

Melalui penghitungan statistik menggunakan software statistik diketahui bahwa tidak terdapat pengaruh antara kompensasi terhadap komitmen organisasi. Berdasarkan uji koefisien determinasi (R2), nilai estimate yang didapatkan dari variabel kompensasi terhadap komitmen organisasi adalah sebesar 0.559 dengan nilai $\mathrm{P}$-value $<0,05$. Artinya variabel kompensasi mempengaruhi komitmen organisasi.

Berdasarkan analisis distribusi responden dengan three box methode, Nilai indeks tertinggi terdapat pada KOM9 indikator penghargaan yaitu "Industri jasa memberikan penghargaan berupa pelatihan diluar industri jasa untuk meningkatkan kompetensi dan keterampilan". Nilai indeks terendah terdapat pada KOM2 indikator gaji yaitu "Gaji yang saya terima sesuai dengan UMR" yaitu 21,6. kompensasi yang diberikan oleh industri jasa belum sesuai dengan harapan tenaga kesehatan terutama pada gaji dimana 95,5\% tenaga kesehatan menyatakan tidak setuju jika gaji sudah sesuai upah minimum regional (UMR).

Analisa distribusi responden pada variabel kompensasi, nilai indeks rendah lainnya terdapat pada indikator gaji memiliki nilai indeks 22 KOM1 yaitu "Gaji yang saya terima mampu memenuhi kebutuhan saya " terdapat $94,02 \%$ tenaga kesehatan tidak setuju dengan pernyataan tersebut. Pada indikator bonus pernyataan KOM6 nilai indeks 22,4 yaitu " Industri jasa rutin memberikan bonus setiap tahunnya" terdapat $94,02 \%$ tenaga kesehatan yang tidak setuju. Pada pernyataan KOM 7 dengan nilai 22,8 yaitu "Bonus yang diberikan sesuai harapan saya" terdapat $94 \%$ karyawan tidak setuju dengan pernyataan tersebut. Artinya hampir seluruh tenaga kesehatan merasa industri jasa tidak memberikan kompensasi atas prestasi dan kinerja baik yang dilakukan oleh tenaga kesehatan, baik kompensasi berupa gaji ataupun bonus.

Kompensasi merupakan salah satu alasan terpenting yang membuat karyawan mau bertahan dan mengembangkan karir pada suatu perusahaan. Salah satu tujuan pemberian kompensasi adalah meningkatkan produktivitas kerja, dimana pemberian kompensasi yang semakin baik akan mendorong karyawan untuk bekerja secara produktif.

Pengaruh motivasi terhadap komitmen organisasi

Berdasarkan hasil pengujian statistik pada nilai estimasi diketahui bahwa motivasi berpengaruh positif dan signifikan terhadap pengembangan karir. Berdasarkan nilai estimasi motivasi memberikan pengaruh $28,1 \%$ terhadap komitmen organisasi, sisanya $71,9 \%$ 
dipengaruhi oleh variabel lain diluar penelitian.

Berdasarkan analisis deskriptif dengan three box methode, Nilai indeks tertinggi 61,4 terdapat pada MOT16 indikator penghormatan yaitu "Seluruh staf di unit harus saling menghargai agar pekerjaan dapat berjalan dengan baik". Nilai indeks terendah terdapat pada MOT4 indikator prestasi yaitu "Rumah skait memberikan penghargaan (bonus tambahan) kepada tenaga kesehatan yang berprestasi", dengan nilai indeks 29,4. Tenaga kesehatan merasakan hubungan antar unit dan staf di industri jasa yaitu adanya sikap saling menghargai sehingga pekerjaan dapat berjalan lancar.

Pada variabel motivasi, analisa deskriptif menghasilkan nilai indeks rendah terdapat pada indikator otoritas yaitu MOT8 dengan nilai indeks 40,2 "Saya mempunyai otoritas dalam menetukan tugas terhadap orang lain"., terdapat $91 \%$ tenaga kesehatan tidak setuju dengan pernyataan tersebut. Artinya masih terdapat tenaga kesehatan yang merasa manajemen industri jasa X Serang Banten tidak memberikan otoritas dalam bekerja. Pada MOT10 nilai indeks 47,2 pada pernyataan "Tenaga kesehatan diberi kesempatan untuk menyampaikan gagasan didalam rapat industri jasa "terdapat $29,8 \%$ tenaga kesehatan yang merasa tidak diberikan kesempatan untuk berbicara pada forum terbuka di industri jasa Artinya tingkat motivasi tenaga kesehatan dalam bekerja di industri jasa X Serang Banten cukup tinggi tetapi pada inditator otoritas belum sepenuhnya diberikan kepada tenaga Kesehatan baik dalam otoritas kepada rekan kerja lain ataupun dalam mengemukakan ide/gagasan.

Motivasi kerja adalah tindakan yang merangsang karyawan untuk mengambil tindakan, yang akan mengarah tercapainya beberapa tujuan atau untuk memenuhi kebutuhan psikologis tertentu dari karyawan (George \& Sabapathy, 2011). Komitmen didefinisikan sebagai keadaan psikologis yang menghubungkan individu dengan organisasi (Meyer \& Allen, 1997). Komitmen karyawan diartikan sebagai upaya karyawan untuk mencapai tujuan organisasi (Mohsan et al., 2011)

Pengaruh komitmen organisasi terhadap retensi tenaga kesehatan

Hasil pengujian statistik di hasilkan bahwa komitmen organisasi berpengaruh positif dan signifikan terhadap retensi tenaga Kesehatan. Dari nilai estimasi pengaruh komitmen organisasi terhadap retensi tenaga kesehatan sebesar 34,2\% dan sisanya $65,8 \%$ dipengaruhi variabel lainnya. Berdasarkan hasil tersebut maka dapat disimpulkan bahwa semakin kuat komitmen organisasi maka tingkat retensi tenaga kesehatan menjadi semakin tinggi. Berdasarkan nilai estimate dan uji indirect, komitmen organisasi terhadap retensi tenaga kesehatan memiliki nilai paling besar dibandingkan kompensasi dan motivasi. Sehingga dapat disimpulkan bahwa komitmen organisasi merupakan faktor perantara antara motivasi dan retensi tenaga kesehatan.

Hasil kesimpulan diatas didukung oleh teori kebutuhan Maslow yang mengemukakan mengenai berbagai kebutuhan dasar manusia yang wajib dipenuhi lebih dahulu kemudian dilanjutkan dengan kebutuhan berikutnya. Berdasarkan atas apa yang dikemukakan Abraham Maslow khususnya pada teori hirarki kebutuhan Maslow, pemenuhan kebutuhan didorong oleh motivasi. Motivasi dalam hal ini adalah motivasi kekurangan (deficiency growth) dan perkembangan (motivation growth). Terdapat lima tingkatan kebutuhan yang dikemukakan oleh teori kebutuhan Maslow, diantaranya kebutuhan fisiologis, 
rasa aman, sosial, penghargaan dan aktualisasi diri. Kelima kebutuhan tersebut disusun pada teori kebutuhan Maslow secara bertingkat dari yang paling mendasar (fisiologis/fisik) hingga yang tertinggi (aktualisasi diri).

Berdasarkan analisis deskriptif, Nilai indeks tertinggi terdapat pada KO7 indikator komitmen normatif yaitu "Saya diajari untuk percaya bahwa seseorang harus setia kepada organisasinya" dengan nilai indeks 59,8. Nilai indeks terendah terdapat pada $\mathrm{KO} 4$ indikator komitmen afektif dengan nilai indeks 34,6 yaitu "Saya merasa sulit untuk terikat dengan industri jasa lain, seperti industri jasa ditempat saya bekerja", terdapat $89,5 \%$ karyawan menyatakan tidak setuju dengan pernyataan tersebut.

Nilai indeks rendah terdapat pada indikator normative pernyataan KO5 dengan nilai indeks 39,4 "Jika saya ditawari pekerjaan yang lebih baik di tempat lain, saya tidak akan meninggalkan industri jasa ini". Pada pernyataan ini terdapat $43,2 \%$ tenaga kesehatan yang tidak setuju dengan pernyataan tersebut. Pernyataan lainnya yang memiliki nilai indeks rendah yaitu pada indikator afektif pernyataan KO1 dengan nilai indeks 46,2 yaitu " Saya merasa senang untuk menghabiskan karir saya di industri jasa ini", terdapat 53,73\% tenaga kesehatan tidak setuju dengan pernyataan tersebut. Artinya masih terdapat tenaga kesehatan yang merasa bahwa jka ada kesempatan

bekerja diluar yang lebih baik, maka tenaga Kesehatan tersebut akan berpindah.

Untuk menumbuhkan komitmen diharapkan perusahaan mampu menjalin hubungan yang baik satu dengan yang lainnya dan perusahaan diharapkan mampu memberikan kontinuitas pelatihan

kepada tiap karyawan dimana nantinya karyawan merasa diperhatikan dan dihargai kemampuannya sehingga memiliki keinginan kuat untuk tetap menjadi bagian didalam perusahaan.

Pengaruh kompensasi terhadap retensi tenaga kesehatan

Berdasarkan hasil penelitian dihasilkan kompensasi berpengaruh positif dan signifikan terhadap retensi tenaga kesehatan. Dari nilai estimasi pengaruh kompensasi terhadap retensi tenaga kesehatan sebesar $34,4 \%$, sisanya $65,6 \%$ dipengaruhi variabel lainnya. Pengaruh kompensasi terhadap retensi tenaga kesehatan secara langsung sebesar 0,350, sedangkan apabila dimediasi oleh komitmen organisasi didapatkan nilai 0,195 (PL > PTL ; 0,350 > 0,195). Dapat di simpulkan kompensasi dapat meningkatkan retensi tenaga kesehatan tanpa harus di mediasi komitmen organisasi. Berdasarkan hasil tersebut maka dapat disimpulkan bahwa kompensasi berpengaruh terhadap retensi tenaga kesehatan. Kompensasi merupakan cara perusahaan untuk meningkatkan kualitas karyawannya untuk pertumbuhan perusahaan. Setiap perusahaan memiliki suatu sistem kompensasi yang berbedabeda sesuai dengan visi, misi, dan tujuannya.

Berdasarkan Analisa deskriptif dengan menggunakan three box method pada variabel kompensasi, nilai indeks rendah lainnya terdapat pada indikator insentif memiliki nilai indeks 23,6 KOM4 yaitu "Insentif yang saya terima sesuai dengan kinerja saya " terdapat $67,16 \%$ tenaga kesehatan tidak setuju dengan pernyataan tersebut. Pada indikator penghargaan pernyataan KOM10 nilai indeks 30,8 "Apabila saya berprestasi Industri jasa memberikan kesempatan untuk melanjutkan Pendidikan dengan biaya ditanggung oleh industri jasa" terdapat $92,53 \%$ tenaga kesehatan yang tidak setuju. Artinya hampir seluruh tenaga Kesehatan merasa insentif dan 
penghargaan yang diberikan oleh industri jasa tidak sesuai dengan harapan.

Menurut William B. Weather dan Keith Davis dimana kompensasi adalah apa yang diterima karyawan sebagai imbalan dari pekerjaan mereka. Baik upah per jam atau gaji berkala,bagian personalia biasanya merancang dan mengelola kompensasi karyawan.

Pengaruh motivasi terhadap retensi tenaga kesehatan

Melalui perhitungan pengujian statistik menggunakan software statistik diketahui bahwa motivasi tidak berpengaruh terhadap retensi tenaga kesehatan. Pengaruh motivasi terhadap retensi tenaga Kesehatan secara langsung adalah 0,237 , sedangkan apabila dimediasi oleh komitmen organisasi didapatkan nilai 0,094 (PL > PTL ; 0,237< 0,094). Dapat disimpulkan motivasi dapat meningkatkan retensi tenaga kesehatan tanpa di mediasi komitmen organisasi.

Berdasarkan Analisa deskriptif dengan three box methode, nilai indeks rendah dengan kategori tinggi terdapat pada MOT7 yaitu 50,4 "Saya memberikan pengaruh positif dalam melaksanakan pekerjaan" terdapat $26,8 \%$ tenaga kesehatan tidak setuju dengan pernyataan tersebut. Pada MOT6 indikator tanggung jawab dengan nilai indeks 57,2 yaitu "Saya mampu mendorong rekan kerja atau bawahan saya dalam menyelesaikan tugas" terdapat $26,8 \%$ tenaga kesehatan tidak setuju dengan pernyataan tersebut. Berdasarkan hasil Analisa deskriptif diatas dapat disimpulkan bahwa tenaga kesehatan merasakan industri jasa tidak mendukung setiap usaha karyawan untuk mencapai tujuan industri jasa dan budaya kerja untuk menjalankan standar operasional prosedur belum dijalankan oleh semua tenaga Kesehatan.

\section{Kesimpulan}

Kompensasi, motivasi dan komitmen organisasi secara simultan berpengaruh positif dan signifikan terhadap retensi tenaga kesehatan. Kompensasi dan motivasi berpengaruh positif dan signifikan terhadap komitmen organisasi dan retensi tenaga kesehatan. Diperlukan strategi agar retensi tenaga kesehatan rumah sakit meningkat dengan cara meningkatkan kompensasi dan motivasi kerja sehingga komitmen tenaga kesehatan terhadap rumah sakit pun akan kuat.

\section{BIBLIOGRAFI}

Agwu, M. (2014). Perception Survey Of Employees Participation In Decision Making And Organizational Productivity In Julius Berger Nigeria PLC Bonny Island. British Journal Of Economics, Management \& Trade, 4(4), 620-637. Google Scholar

Banu, L. (2018). Implementasi Hukum Pasal 35 Undang-Undang Nomor 39 Tahun 2004 Dalam Program Recognised Seasonal Employment. Jurnal Magister Hukum Udayana (Udayana Master Law Journal), 7(1), 91. Google Scholar

Basri, N. R. (2014). Hubungan Gula Darah Sewaktu Dengan Kejadian Fluor Albus Pada Wanita Hamil Usia 13-40 Minggu Di RS Prikasih Pondok Labu Periode Januari-April 2014. Google Scholar

Listiyani, K. N. K. (2011). Manajemen Pembinaan Peserta Didik Di Smp Negeri 3 Ceper Kabupaten Klaten. 1172. Google Scholar

Mathis, R. L., \& Jackson, J. H. (2006). Human Resource Management: Manajemen Sumber Daya Manusia. Terjemahan Dian Angelia. Jakarta: Salemba Empat. Google Scholar

Mcclelland, D. C. (1987). Human Motivation. CUP Archive. Google Scholar 
Meyer, J. P., \& Allen, N. J. (1997). Commitment In The Workplace: Theory, Research, And Application. Sage Publications. Google Scholar

Ngure, P., \& Waiganjo, E. (2017). Factors Influencing Retention Of Health Workers In The Public Health Sector In Kenya: A Case Study Of Kenyatta National Hospital. International Journal Of Scientific And Research Publications, 7(5), 818. Google Scholar

Potale, R., \& Uhing, Y. (2015). Pengaruh Kompensasi Dan Stres Kerja Terhadap Kepuasan Kerja Karyawan Pada PT. Bank Sulut Cabang Utama Manado. Jurnal EMBA: Jurnal Riset Ekonomi, Manajemen, Bisnis Dan Akuntansi, 3(1). Google Scholar

Susanti, R., Hasyim, ., \& Rita, K. (2020). Turnover Intention And Behavior
Organizational Citizenship On Indonesian Hospital Case. European Journal Of Business And Management Research, 5(4), 1-6. Google Scholar

Wardani, A. (2016). Implementasi Konvensi PBB Tahun 1990 Tentang Perlindungan Buruh Migran Beserta Anggota Keluarga Oleh Pemerintah Indonesia. Universitas Jember. Google Scholar

Wati, K. D., Herawati, N. T., AK, S. E., \& SINARWATI, N. I. K. (2014). Pengaruh Kompetensi SDM, Penerapan SAP, Dan Sistem Akuntansi Keuangan Daerah Terhadap Kualitas Laporan Keuangan Daerah. JIMAT (Jurnal Ilmiah Mahasiswa Akuntansi) Undiksha, 2(1). Google Scholar

Werther, W. B., \& Davis, K. (1989). Human Resources And Personnel Management. Harper San Francisco. Google Scholar

\section{Copyright holder:}

Maratu Solihah, Ratna Indrawati, Hasyim (2022)

First publication right:

Jurnal Health Sains

This article is licensed under:

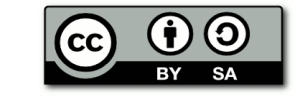

